The basic endocrine defect in Klinefelter syndrome appears to be gonadal. The relative roles of the testicular structure and function observed at puberty and elevated gonadotropin secretion is not presently understood. We found that during childhood, serum gonadotropin levels are normal even following GnRH stimulation. By midpuberty, Klinefelter subjects are hypergonadotropic, even though their basal $\mathrm{T}$ levels are not markedly reduced and $T$ secretion can be increased further either by the administration of hCG or infusion of sufficient GnRH to raise endogenous LH even further. It would appear that high circulating gonadotropin levels may exacerbate the primary testicular lesion and cause the progressive hyalinization and fibrosis. Eventually, testicular damage or a local effect of intratesticular estrogen leads to diminished $T$ reserve. It remains to be seen to what extent early aggressive $T$ therapy might influence the course of this adolescent endocrine dysfunction.

Acknowledgments. The authors thank Dr. John F. LaBrecque for statistical consultation and Jean Clyne for help in preparation of the manuscript.

\section{REFERENCES}

1. Ahmad KN, Dykes JRW, Ferguson-Smith MA, Lennox B, Mack WS 1971 Leydig cell volume in chromatin-positive Klinefelter's syndrome. $J$ Clin Endocrinol Metab 33:517.

2. Blank B, Attanasio A, Rager K, Gupta D 1978 Determination of serum sex hormone binding globulin (SHBG) in preadolescent and adolescent boys. $J$ Steroid Biochem 9:121

3. Carlson HE 1980 Gynecomastia. N Engl J Med 303:795

4. Faiman C, Ryan RJ 1967 Radioimmunoassay for human follicle stimulating hormone. J Clin Endocrinol Metab 27:444

5. Faiman C, Ryan RJ 1967 Radioimmunoassay for human luteinizing hormone. Proc Soc Exp Biol Med 125:1130

6. Ferguson-Smith MA 1959 The prepubertal testicular lesion in chromatin- positive Klinefelter's syndrome (primary micro-orchidism) as seen in mentally handicapped children. Lancet $1: 219$

7. Forti G, Giusti G, Borghi A, Pazzagli M, Fiorelli G, Cabresi E, Mannelli M, Bassi F, Giannotti P, Fusi S, Serio M 1978 Klinefelter's syndrome: a study of its hormonal plasma pattern. J Endocrinol Invest 2:149

8. Gabrilove JL, Freiberg EK, Thornton JC, Nicolis GL 1979 Effect of age on testicular function in patients with Klinefelter's syndrome. Clin Endocrinol $11: 343$

9. Lee PA 1975 The relationship of concentrations of serum hormones to pubertal gynecomastia. J Pediatr 86:212

10. Pomerantz DK 1983 Interactions of follicle-stimulating hormone and luteinizing hormone in controlling estradiol synthesis by the testis of the infant rat. Biol Reprod 28:890

11. Ratcliffe SG, Bancroft J, Axworthy D, McLaren W 1982 Klinefelter's syndrome in adolescence. Arch Dis Child 57:6

12. Robinson A, Puck M, Pennington B, Borelli J, Hudson M 1979 Abnormalities of the sex chromosomes: a prospective study on randomly identified newborns. In: Robinson A, Lubs HA, Bergsma D (eds) Sex Chromosome Aneuploidy: Prospective Studies on Children. Birth Defects 15:203

13. Sharma DC, Gabrilove JL 1971 Biosynthesis of testosterone and oestrogens in vitro by the testicular tissue from patients with Klinefelter's syndrome. Acta Endocrinol 66:737

14. Robinson A, Bender B, Puck M, Salbenblatt J, Webber L 1982. In: Stewart DA (ed) Children with Sex Chromosome Aneuploidy: Follow-up Studies, Birth Defects 18:7

15. Topper E, Dickerman Z, Prager-Lewin R, Kaufman H, Maimon Z, Laron Z 1982 Puberty in 24 patients with Klinefelter syndrome. Eur J Pediatr 139:8

16. Winter JSD 1978 Prepubertal and pubertal endocrinology. In: Faulkner F, Tanner JM (eds) Human Growth, Vol. 2. Postnatal Growth. Plenum Press, New York, pp 183-213

17. Winter JSD, Faiman C 1972 Pituitary-gonadal relations in male children and adolescents. Pediatr Res 6:126

18. Winter JSD, Faiman C 1972 Serum gonadotropin concentrations in agonadal children and adults. J Clin Endocrinol Metab 35:561

19. Winter JSD, Hughes IA, Reyes FI, Faiman C 1976 Pituitary-gonadal relations in infancy: 2. Patterns of serum gonadal steroid concentrations in man from birth to two years of age. J Clin Endocrinol Metab 42:679

20. Winter JSD, Taraska S, Faiman C 1972 The hormonal response to hCG stimulation in male children and adolescents. $\mathrm{J}$ Clin Endocrinol Metab $34: 348$

\title{
Studies on Requirements for Amino Acids in Infants with Disorders of Amino Acid Metabolism. I. Effect of Alanine
}

\author{
DREW G. KELTS, DENISE NEY, ${ }^{1}$ CAROLYN BAY, JEAN-MARIE SAUDUBRAY, AND \\ WILLIAM L. NYHAN \\ Department of Pediatrics [D.G.K., C.B., J-M.S., W.L.N.] and the General Clinical Research Center [D.N.], \\ University of California San Diego Medical Center, San Diego, California 92103
}

\begin{abstract}
Two infants with disorders of propionate metabolism were studied at 7 months of age to determine optimum levels of intake of protein and calories to meet the requirements for essential amino acid for growth in
\end{abstract}

Received December 1, 1983; accepted August 1, 1984.

Reprint request to Dr. William L. Nyhan, Department of Pediatrics, M-009, UCSD School of Medicine, La Jolla, CA 92093

Aided in part by the UCSD General Clinical Research Center National Institutes of Health Division of Research Resources, Grant RR-00827 and Grant 04608 from the National Institute of Child Health and Human Development, National Institutes of Health, Bethesda, MD.

This work performed whib J-M.S. was on sabbatical from Hospital NeckerEnfants Malades, Clinique Genetique Salle Gillette 149 Rue de Sevres, Paris, France 75730

' Present address; c/o Nutrition Department, UC Davis, Davis, CA 95616. infancy, and at the same time minimize the accumulation of toxic intermediates. An effect of alanine was found that permitted growth at otherwise limiting levels of protein intake. This was not simply an effect of nonessential nitrogen as neither glycine nor glutamic acid could substitute for alanine in this protein-sparing effect. This appears to represent further evidence of the relationship between alanine and the branched-chain amino acids and of the importance of the alanine-glucose cycle in human physiology. (Pediatr Res 19: 86-91, 1985)

Abbreviation

BA, baseline period 
Studies of nutrition in infancy have sought to establish minimum requirements of essential amino acids using diets in which there were deficient or minimal intakes of specific amino acids, or by extrapolating values from the diets of infants growing normally $(2,5,7,8,10-12,14,16,17)$. It has generally been assumed that growth is limited by the amount of available essential amino acids. Nitrogen balance is also helpful but less so in that infants stop growing at reduced levels of amino acid intake at which nitrogen balance is still positive. Each of these measures is more useful in determining satisfactory levels at which normal growth will proceed than in determining actual minimal requirements. Furthermore, the values employed in nutritional counseling represent the upper level of the ranges obtained in studies on amino acid requirements $(5,8,14)$. This is appropriate in the management of normal individuals, but it may provide toxic levels of precursor in an infant with an inherited disorder of metabolism. Initial experience led us to conclude that accepted values for requirements were generous $(21,22)$. For these reasons we began a systematic study of the requirements of amino acids in infants and children with inborn errors of metabolism (20). We and others have hypothesized that infants with inborn errors of amino acid metabolism provide a unique opportunity to determine minimal requirements of essential amino acids $(26,29)$. Since these disorders represent defects in metabolism, metabolites accumulate whenever intake exceeds requirements. Using the measurement of the accumulating metabolite to keep amino acid intake equal to the rate of turnover at the level of anabolic requirements permits a very precise definition of minimal requirements, as assessed by growth in weight and nitrogen balance. The addition of the accumulating metabolite or metabolites permits a determination of a floor as well as the ceiling provided by rates of growth and nitrogen balance to the ranges obtained in any individual infant. In addition at minimal levels of amino acid intake, the contribution of supplemental nonessential nitrogen can be readily assessed.

Patients with disorders of propionate metabolism are specifically intolerant of branched-chain amino acids. Because of the site of the enzyme defects they cannot properly metabolize isoleucine, threonine, methionine, and valine. Leucine does not follow this catabolic pathway, but patients with propionic acidemia are highly intolerant of leucine (3). Branched chain amino acids are thought to be preferentially catabolized in muscle where they provide a major nitrogen source for the biosynthesis of alanine from pyruvate in the alanine-glucose cycle $(6,28)$. Alanine so formed from carbohydrate in muscle is transported to the liver where it is converted first to pyruvate and then to glucose. It was reasoned that the provision of alanine in amounts additional to those found in dietary whole protein might spare the catabolism of essential amino acids in muscle, permitting optimal growth on lower levels of potentially toxic precursors and lower levels of accumulation of toxic intermediates. The design of the experiment was to determine the level of protein intake just below that at which growth occurred, and then to assess the effects of supplemental alanine. It was found that the addition of alanine permitted the resumption of growth at rates equivalent to those of higher levels of protein intake. That this was not simply an effect of nonessential nitrogen was indicated by the failure of glycine or glutamic acid to substitute for alanine.

\section{PATIENTS AND METHODS}

E.A. was a 7-month-old Libyan female with propionic acidemia. There was close consanguinity in that the father's father and the mother's grandfather were brothers. A previous male sibling had died of the disease. C.H. was a 7-month-old female with methylmalonic acidemia. A previous sibling had died of the disease. Studies were carried out in the General Clinical Research Center at the UCSD Medical Center. E.A. was 8 months old at the completion of the baseline nutritional studies, and was 11 months old at the completion of the entire study. C.H. vas 8 months old at the completion of the baseline nutritional studies, and was 14 months old at the completion of the entire study.

Both infants were maintained on a specially formulated diet in which the caloric intake was provided by mixtures of Enfamil (Mead Johnson and Co., Evansville, IN) as the protein source, and Mead Johnson Product 80056, to provide additional carbohydrate and fat. Polycose (Ross Laboratories, Columbus, $\mathrm{OH}$ ) glucose polymer and/or corn oil were used to supplement calories as needed. Additional vitamins, trace elements, and iron were provided at maintenance requiremets. Caloric distribution was approximately $40 \%$ as carbohydrate, $55 \%$ as fat, and $3-5 \%$ protein. The caloric density of each formula was approximately $1 \mathrm{kcal} / \mathrm{ml}$.

In studies on E.A. two basic formats were employed (Table 1). In the first she received $100 \mathrm{kcal} / \mathrm{kg}$, and a fixed dose of protein was employed, $5.0 \mathrm{~g}$ in the initial baseline period and $4.0 \mathrm{~g}$ thereafter. In the second (cycles $E$ through $J$ ) the caloric intake was reduced to $80 \mathrm{kcal} / \mathrm{kg}$ and, after an initial cycle at $5.0 \mathrm{~g}$, a protein intake of $0.75 \mathrm{~g} / \mathrm{kg}$ was prescribed. After the baseline period of $3 \mathrm{wk}$ of a diet containing $100 \mathrm{kcal} / \mathrm{kg}$ day and $0.75 \mathrm{~g}$ protein $/ \mathrm{kg} /$ day (Table 1), the infant underwent a series of 7-day studies. In each cycle an initial 4 days was considered to provide a steady state following dietary change, after which stool and urine for nitrogen balance were collected during the last 3 days of each cycle. L-Alanine, glycine and L-glutamic acids were added as the crystalline amino acids (Ajinomoto Co., Inc., Tokyo, Japan). The formula was fed by continuous nasal gastric infusion and any lost through emesis was replaced. Formulations were calculated on the basis of the weight at the beginning of each cycle. Intake was calculated based on manufacturer's product

Table 1. Intake of protein and calories in relation to growth in wt and nitrogen balance (effect of alanine on patient E.A.)*

\begin{tabular}{|c|c|c|c|c|c|c|c|c|}
\hline \multirow[b]{2}{*}{ Cycle } & \multirow[b]{2}{*}{$\mathrm{kcal} / \mathrm{kg}$} & \multicolumn{3}{|c|}{ Protein intake $(\mathrm{mg} / \mathrm{kg})$} & \multirow{2}{*}{$\begin{array}{c}\mathrm{N}(\mathrm{mg} / \\
\mathrm{kg})\end{array}$} & \multirow[b]{2}{*}{$\mathrm{kcal} / \mathrm{N}$} & \multirow{2}{*}{$\begin{array}{c}\begin{array}{c}\mathrm{N} \text { balance } \\
(\mathrm{mg} / \mathrm{kg})\end{array} \\
\end{array}$} & \multirow{2}{*}{$\begin{array}{l}\text { Wt gain } \\
\text { (g/day) }\end{array}$} \\
\hline & & Enfamil & + & AA & & & & \\
\hline BA & 100 & $750^{\circ}$ & + & 0 & 120 & 833 & 53 & 23 \\
\hline $\mathrm{A}(\mathrm{AL})$ & 100 & 750 & + & 177 & 148 & 675 & 69 & 23 \\
\hline B & 100 & 580 & + & 0 & 92 & 1086 & 38 & 15 \\
\hline$C(\mathrm{AL})$ & 100 & 560 & + & 141 & 112 & 892 & 58 & 23 \\
\hline$D(G Y)$ & 100 & 550 & + & 138 & 110 & 909 & 41 & 7 \\
\hline$E(A L)$ & 80 & 680 & + & 136 & 130 & 615 & 63 & 13 \\
\hline$F$ & 80 & 680 & + & 0 & 108 & 740 & 53 & -2 \\
\hline $\mathrm{G}(\mathrm{AL})$ & 80 & 670 & + & 132 & 128 & 625 & 65 & 30 \\
\hline $\mathrm{H}(\mathrm{GU})$ & 80 & 670 & + & 130 & 127 & 629 & 58 & 0 \\
\hline $\mathrm{I}(\mathrm{AL})$ & 70 & 670 & + & 130 & 128 & 546 & 66 & -8 \\
\hline $\mathrm{J}(\mathrm{AL})$ & 75 & 670 & + & 130 & 128 & 546 & 67 & 10 \\
\hline
\end{tabular}

* Abbreviations: AL, alanine; GY, glycine; GU, glutamic acid; AA, amino acid. (The patient was 8 months old at the completion of cycle BA and 11 months old at the completion of the study with cycle J.) 
Table 2. Intake of protein and cal in relation to growth in wt and $N$ balance (effect of alanine in patient C.H.)*

\begin{tabular}{|c|c|c|c|c|c|c|c|c|}
\hline \multirow[b]{2}{*}{ Cycle } & \multirow[b]{2}{*}{$\mathrm{kcal} / \mathrm{kg}$} & \multicolumn{3}{|c|}{ Protein Intake $(\mathrm{mg} / \mathrm{kg})$} & \multirow{2}{*}{$\begin{array}{c}\mathrm{N}(\mathrm{mg} / \\
\mathrm{kg})\end{array}$} & \multirow[b]{2}{*}{$\mathrm{kcal} / \mathrm{N}$} & \multirow{2}{*}{$\begin{array}{c}\text { N balance } \\
(\mathrm{mg} / \mathrm{kg})\end{array}$} & \multirow{2}{*}{$\begin{array}{l}\text { Wt gain } \\
\text { (g/day) }\end{array}$} \\
\hline & & Enfamil & + & AA & & & & \\
\hline $\mathrm{BA}$ & 100 & 800 & + & 0 & 128 & 781 & 58 & 20 \\
\hline$A(A L)$ & 100 & 600 & + & 154 & 121 & 826 & 59 & 23 \\
\hline B & 100 & 600 & + & 0 & 96 & 1041 & 34 & 10 \\
\hline $\mathrm{C}(\mathrm{AL})$ & 80 & 600 & + & 150 & 120 & 666 & 41 & 20 \\
\hline $\mathrm{D}$ & 75 & 550 & + & 0 & 88 & 852 & 41 & 1 \\
\hline $\mathrm{E}(\mathrm{AL})$ & 75 & 550 & + & 108 & 105 & 714 & 48 & 30 \\
\hline$F$ & 75 & 600 & + & 0 & 96 & 781 & 38 & 29 \\
\hline
\end{tabular}

* Abbreviations as in Table 1. (The patient was 8 months of age at the completion of cycle BA and 14 months of age at the completion of cycle F.)

information and standard dietary tables. The effect of alanine was observed in the course of these studies. Studies were then undertaken in C.H. (Table 2) in which the intake of protein was systematically varied between 0.8 and $0.55 \mathrm{~g} / \mathrm{kg}$.

Patients were weighed daily in the nude. The rate of change in weight was calculated from initial to final day and divided by the number of days in the cycle. The pattern growth in weight was required to be continuous throughout a cycle in order to exclude shifts of fluid that might occur in the first days of a cycle. Furthermore, cycles were required to be at least 7 days in duration, and we did not prolong a period of study in which no weight gain was occurring. However, some of the successful cycles, especially those in which alanine was added, were continued for weeks, during which time there was continued maintenance of rates of growth. Nitrogen excretion was determined on three 24-h urine and 72-h stool collections by a modified Kjeldahl method (N. M. Alexander, unpublished data), using the Berthelot reaction, and the results were averaged.

\section{RESULTS}

During the BA (Table 1), E.A. was in positive nitrogen balance and had an average weight gain of $23 \mathrm{~g} / \mathrm{day}$. The $5.0 \mathrm{~g}$ of protein represented $0.75 \mathrm{~g} / \mathrm{kg}$. The addition of $1.0 \mathrm{~g}$ of alanine $(177 \mathrm{mg} /$ $\mathrm{kg}$ ) in cycle $\mathrm{A}$ induced further positive nitrogen balance but did not alter the rate of growth in weight. When the intake of protein was reduced to $4.0 \mathrm{~g}$ (cycles B-D) it amounted to $0.58 \mathrm{~g} / \mathrm{kg}$ (cycle B). Weight gain was reduced to $15 \mathrm{~g} /$ day and nitrogen balance decreased. The addition of alanine (cycle $\mathrm{C}$ ) restored the rate of weight gain to $23 \mathrm{~g} /$ day, the baseline level, and increased nitrogen balance. Provision of an equal amount of nitrogen as glycine (cycle D) did not permit a satisfactory gain in weight.

In the second series of experiments (cycles $\mathrm{E}$ and $\mathrm{F}$ ), the caloric intake was decreased to $80 \mathrm{kcal} / \mathrm{kg} / \mathrm{day}$, while the intake of nitrogen as protein was increased to $5.0 \mathrm{~g} /$ day. In the absence of the alanine (cycle F) there was loss of weight at this level of caloric and protein intake $(0.68 \mathrm{~g} / \mathrm{kg})$, while supplementation with alanine (cycle E) resulted in a gain of $13 \mathrm{~g} /$ day in weight. In all subsequent cycles protein intake was provided in $\mathrm{g} / \mathrm{kg}$ per cycle. In cycle $G$ the provision of alanine supplement at $80 \mathrm{kcal} /$ $\mathrm{kg}$ and $0.67 \mathrm{~g} / \mathrm{kg}$ of protein led to a weight gain of $30 \mathrm{~g} /$ day. Substitution of glutamic acid for alanine (cycle $H$ ) failed to promote weight gain despite positive nitrogen balance.

Reduction of the caloric intake to $70 \mathrm{kcal} / \mathrm{kg}$ (cycle I) abolished weight gain at $0.67 \mathrm{~g} / \mathrm{kg}$ of protein despite alanine supplementation. At this level caloric intake appeared to be limiting. Increasing the caloric intake to $75 \mathrm{kcal} / \mathrm{kg}$ (cycle $\mathrm{J}$ ) restored weight gain. Comparison of cycle $F$ with $\mathrm{BA}$ in which $5 \mathrm{~g}$ of protein were provided indicated again the influence of caloric intake, for quite satisfactory gain in weight was seen at $100 \mathrm{kcal} /$ $\mathrm{kg}$ and there was weight loss at $80 \mathrm{kcal} / \mathrm{kg}$. Of course the patient's weight had increased during this time so the protein intake had decreased from 0.75 to $0.68 \mathrm{~g} / \mathrm{kg}$. However, in cycle B a level of protein intake of $0.58 \mathrm{~g} / \mathrm{kg}$ was associated with satisfactory gain in weight at $100 \mathrm{kcal} / \mathrm{kg}$. The experiments shown in Table 1 represented a substantial passage of time in which the patient's requirements for protein and calories were decreasing. Thus in the last two cycles, nitrogen retention was excellent, but she did not grow when receiving less than $75 \mathrm{kcal} / \mathrm{kg}$.

In experiments with C.H. (Table 2), experience gained with E.A. permitted the systematic alteration of the separate variables demonstrating the ability of alanine to substitute for protein at limiting levels of protein intake. As protein was decreased from $0.8 \mathrm{~g} / \mathrm{kg}$ in the BA to $0.6 \mathrm{~g} / \mathrm{kg}$ in cycle A there was no decrease in the rate of weight gain when $1.0 \mathrm{~g} / \mathrm{kg}$ of alanine was provided. Removal of the alanine in cycle B led to reduced rate of weight gain. These experiments were carried out with a generous supply of calories at $100 \mathrm{kcal} / \mathrm{kg}$. Reduction of caloric intake to $80 \mathrm{kcal} /$ $\mathrm{kg}$ in cycle $\mathrm{C}$ at $0.6 \mathrm{~g} / \mathrm{kg}$ of protein in the presence of alanine led to the same rate of gain as in the BA. Lowering of the caloric intake to $75 \mathrm{kcal} / \mathrm{kg}$ and of protein intake to $0.55 \mathrm{~g} / \mathrm{gk}$ in cycle $D$ resulted in cessation of weight gain again. This established the lower limits of caloric and protein intake. The addition of alanine restored weight gain to the baseline level or above (cycle $\mathrm{E}$ ), as did the supply of additional protein in cycle $F$ to $0.6 \mathrm{~g} / \mathrm{kg}$. Nitrogen balance was very little different on all of these regimens. Nevertheless, it was always greater in the presence of alanine. It was concluded that at this age at an intake of $75 \mathrm{kcal} / \mathrm{kg}, 0.6 \mathrm{~g} /$ $\mathrm{kg}$ of whole protein was a limiting level below which growth would not occur. However, in the presence of added alanine, growth proceeded at $0.55 \mathrm{~g} / \mathrm{kg}$, a level below this inflection point. In interpreting these data it is important to comment that experiments like this take time and by the time the patient had reached cycles $\mathrm{D}, \mathrm{E}$, and $\mathrm{F}$ she was older than in cycles $\mathrm{A}, \mathrm{B}$, and $\mathrm{C}$, and her requirements for protein and calories had decreased. Thus she grew much better while receiving $0.6 \mathrm{~g} / \mathrm{kg}$ of protein and only $75 \mathrm{kcal} / \mathrm{kg}$ in cycle $F$ than on $0.6 \mathrm{~g} / \mathrm{kg}$ and $100 \mathrm{kcal} / \mathrm{kg}$ in cycle $\mathrm{B}$. In this series of studies we believe it is appropriate to compare cycles $\mathrm{BA}, \mathrm{A}$, and $\mathrm{C}$ and separately to compare cycles $D, E$, and $F$.

Data on the excretion of organic acid metabolites are shown in Table 3. All of these concentrations represent excellent levels of control. In C.H. the excretion of methylmalonic acid was a little less in cycle $\mathrm{A}$ when she received alanine than in cycle BA, the baseline. In E.A. the excretions of methylcitric acid and 3hydroxypropionic acid were very low during the baseline period. The other values are more representative of a very good level of control in this patient. It is specifically of interest that the levels were not higher during the period of glycine administration in cycle $D$ than in the period of alanine administration. Concentrations of amino acids in the plasma are shown in Table 4 . Neither patient was appreciably hyperglycinemic during this study. Also the concentration of glycine in the plasma during cycle $\mathrm{D}$ when glycine was fed to E.A. was no greater than in the baseline period.

\section{DISCUSSION}

These observations indicate that alanine has a protein-sparing anabolic effect that permits growth at levels of essential amino acids below those usually required for growth. This was clearly 
Table 3. Organic acid metabolites of urine

\begin{tabular}{|c|c|c|c|c|}
\hline \multirow[b]{2}{*}{ Patient } & \multirow[b]{2}{*}{ Cycle } & $\begin{array}{l}\text { Methylmalonic } \\
\text { acid }\end{array}$ & $\begin{array}{l}\text { Methylcitric } \\
\text { acid }\end{array}$ & $\begin{array}{l}\text { 3-Hydroxypropionic } \\
\text { acid }\end{array}$ \\
\hline & & \multicolumn{3}{|c|}{$(\mu \mathrm{m} / \mathrm{mg}$ creatinine $)$} \\
\hline \multirow[t]{2}{*}{ C.H. } & BA & 24.9 & & \\
\hline & A & 20.5 & & \\
\hline \multirow[t]{3}{*}{ E.A. } & BA & & 8.7 & ND \\
\hline & D & & 17.2 & 1.4 \\
\hline & $\mathbf{J}$ & & 19.1 & 1.8 \\
\hline
\end{tabular}

Table 4. Concentrations of amino acids in plasma

\begin{tabular}{lccc}
\hline $\begin{array}{c}\text { Patient } \\
\text { Cycle }\end{array}$ & $\begin{array}{c}\text { E.A. } \\
\text { BA } \\
(\mathrm{mg} / \mathrm{dl})\end{array}$ & $\begin{array}{c}\text { E.A. } \\
\text { D } \\
(\mathrm{mg} / \mathrm{dl})\end{array}$ & $\begin{array}{c}\text { C.H. } \\
\text { BA } \\
(\mathrm{mg} / \mathrm{dl})\end{array}$ \\
\hline Amino acid & & & \\
Threonine & 1.1 & 0.8 & 1.2 \\
Serine & 2.0 & 1.8 & 2.9 \\
Glutamine & 5.9 & 10.8 & 5.1 \\
Proline & 1.8 & 1.6 & 3.0 \\
Glutamic acid & 2.0 & 1.3 & 1.8 \\
Glycine & 5.5 & 5.2 & 3.2 \\
Alanine & 3.3 & 3.9 & 6.3 \\
Valine & 0.6 & 0.6 & 0.8 \\
Isoleucine & 0.3 & 0.3 & 0.4 \\
Leucine & 0.5 & 0.5 & 0.6 \\
Tyrosine & 0.2 & 0.2 & 0.6 \\
Phenylalanine & 0.4 & 0.6 & 0.7 \\
Lysine & 0.8 & 0.9 & 0.4 \\
Histidine & 1.0 & 0.7 & 1.1 \\
\hline
\end{tabular}

shown in studies on C.H. In addition in experiments with E.A., there was no growth when less than $0.7 \mathrm{~g} / \mathrm{kg}$ was supplied on a diet containing $80 \mathrm{kcal} / \mathrm{kg}$. However, the provision of additional alanine demonstrated an excellent rate of weight gain at this limiting level of protein and caloric intake, which was as good as or better than that observed at $0.75 \mathrm{~g} / \mathrm{kg}$ of protein and 100 $\mathrm{kcal} / \mathrm{kg}$. That this was not a nonspecific effect of supplementation with nonessential nitrogen was demonstrated by the fact that neither glycine nor glutamate could effectively substitute for alanine. It is important to emphasize that these infants were growing on these very low protein intakes on which growth in weight was demonstrated. They have been maintained on such regimens over long periods of time in which other measures of growth such as increase in length and head size have occurred. Both patients are approaching the age of $4 \mathrm{yr}$ at the time of this report; both are still receiving very low intakes of protein and are continuing to grow and develop.

Snyderman et al. (30) classically demonstrated that nonessential nitrogen could be limiting in studies of four infants on restricted protein intakes. They had initially found that there was a discrepancy between the calculated requirements for essential amino acids and actual intake required to maintain positive nitrogen balance in adults and postulated that additional nitrogen was required. In adults receiving dietary protein from cow's milk an intake of $0.5 \mathrm{~g} / \mathrm{kg} /$ day was required to maintain nitrogen balance, while data from Rose and Dekker (25), indicated that using amino acids $0.2 \mathrm{~g} / \mathrm{kg} /$ day should have been requind. They then studied four infants in whom cow's milk protein was supplemented with urea or glycine. It is important to recognize that the design of their experiments was different from that of our studies. Using isocaloric diets based on cow's milk as the source of protein, protein intake was reduced to a point at which gain was reduced. Supplementation with glycine or urea restored growth in weight. Stable isotopic studies using N-15 urea demonstrated incorporation of the additional nitrogen into protein.
This nitrogen requirement from other than essential amino acids has been called "unessential" or "nonessential" nitrogen. Picou and Phillips (23), in studies of children recovering from malnutrition, have also shown the incorporation of $\mathrm{N}-15$ labeled urea into protein. The amount of incorporation into protein was proportional to the degree of deprivation.

The four infants studied by Snyderman et al. (30) were $3 \mathrm{wk}$ to 5 months of age. The protein intakes at which the rate of growth fell off ranged from $1.32-1.1 \mathrm{~g} / \mathrm{kg} /$ day. It was of interest that when intake of protein was reduced further to the point at which growth in weight ceased, supplemental nonessential nitrogen could not restore growth. These were the conditions in our experiments in which alanine was effective but glycine was not.

At the low levels of protein intake studied, the effect of any essential nitrogen would be significant. Both patients demonstrated an improved nitrogen retention at all caloric levels when supplemental alanine was provided. The levels of nitrogen retention in the studies were low, and the differences observed may not exceed the limits of error of the method. Nevertheless, in each comparison made the retention of nitrogen was greater in the presence of alanine. The most critical comparison indicated that this retention was not simply the provision of nonessential nitrogen. This was tested by the provision of supplemental glycine and glutamic acid and neither improved nitrogen retention.

Alanine was chosen for these studies because of its key role in energy metabolism and in that of the branched-chain amino acids, which are the precursors of the intermediates of propionate metabolism that accumulate and are considered to cause clinical illness in propionic acidemia and methylmalonic acidemia. In studies of arteriovenous differences, alanine is released from muscle in amounts disproportionate to those of other amino acids or its concentration in muscle $(6,19,28)$. It is synthesized by conversion of pyruvate to alanine in muscle. In this alanineglucose cycle (Fig. 1), alanine formed in muscle is transported to the liver where it serves as the predominant precursor for hepatic gluconeogenesis $(6,19,24)$. In liver, alanine is readily converted to pyruvate and then to glucose and glycogen $(6,24,28)$. In muscle, alanine is formed by the transamination of glutamate and pyruvate. Glutamate in turn is formed from $\alpha$-ketoglutarate by transamination. The branched-chain amino acids serve as a preferential source of nitrogen for the synthesis of alanine from pyruvate $(18,19)$. These amino acids are preferentially catabolized in muscle (19). This catabolism generates amino groups which cannot be converted to urea in muscle as they are in liver and are converted to alanine by transamination of pyruvate (13). Branched-chain amino acid transferase and alanine amino acid transferase are in close proximity intracellularly (4) and are

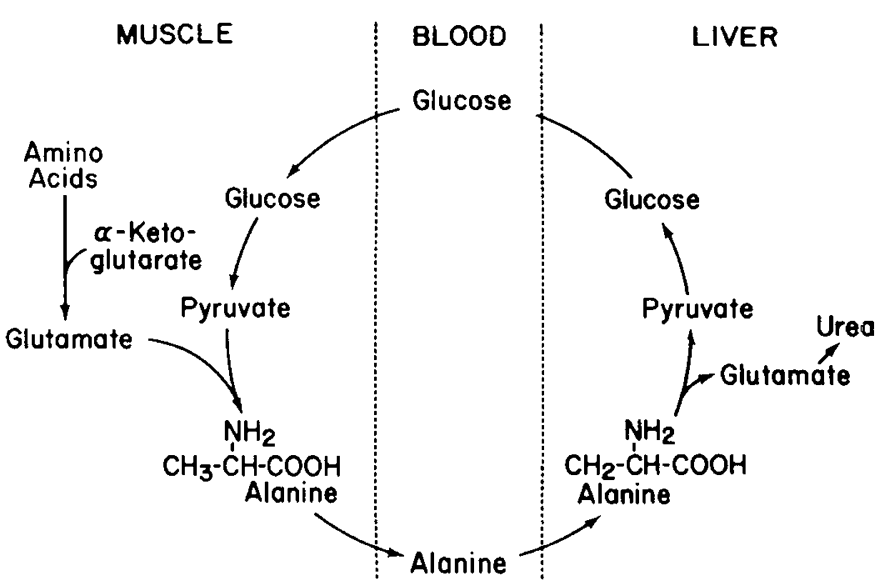

Fig. 1. The glucose-alanine cycle. Alanine is biosynthesized in muscle via transamination, accepting nitrogen resulting from the catabolism of amino acids, and is transported to the liver where it is a substrate for gluconeogenesis. It was hypothesized that the provision of exogenous alanine would spare the catabolism of amino acids. 
reciprocally regulated (28). Furthermore, leucine has recently been shown to serve as a major source of the nitrogen of circulating alanine in vivo (1). We reasoned that the provision of exogenous alanine might serve to spare the peripheral catabolism of essential brached-chain amino acids in an otherwise limiting situation, and make them available for anabolism. If a major function of the catabolism of leucine and the other branchedchain amino acids in muscle is to provide a source of alanine for gluconeogenesis, it seemed reasonable that if a plentiful source of alanine were provided in the diet, that this catabolic pathway might be susceptible to regulation and decrease. Since the source of this catabolic pathway is whole muscle protein, sparing its catabolism would also potentially diminish the provision of isoleucine, threonine, methionine, and valine, and hence diminish the production of propionate and its products.

A caloric effect was also evident in these studies. At intakes of $100 \mathrm{kcal} / \mathrm{kg}$ in the absence of alanine, adequate growth in weight was observed at protein intakes of $0.58 \mathrm{~g} / \mathrm{kg}$ in E.A. and $0.6 \mathrm{~g} /$ $\mathrm{kg}$ in C.H., while at $80 \mathrm{kcal} / \mathrm{kg}$ in E.A. there was no growth at $0.67 \mathrm{~g} / \mathrm{kg}$. A similar protein-sparing effect when calories were provided at more than limiting quantities was reported by Satoh et al. (27) in studies on patients with methylmalonic acidemia. On a borderline intake of protein of $0.6 \mathrm{~g} / \mathrm{kg}$ progressive reduction of caloric intake from 100 to $80 \mathrm{kcal} / \mathrm{kg}$ led to a progressive increase in the urinary excretion of methylmalonic acid. Concomitantly, the rate of gain in weight slowed.

In the management of infants with disorders of propionate metabolism, it appears prudent to restrict the intake of the branched-chain amino acid precursors of propionate to the minimal levels required for optimal anabolism. The Enfamil formula contained $53.2 \mathrm{mg}$ of isoleucine, $63.4 \mathrm{mg}$ of valine, $25.9 \mathrm{mg}$ of methionine, and $45.6 \mathrm{mg}$ of threonine per gram of protein. At 0.6 and $0.8 \mathrm{~g} / \mathrm{kg}$ of protein the amounts of these amino acids provided were: $32-43 \mathrm{mg} / \mathrm{kg}$ of isoleucine, $38-51 \mathrm{mg} / \mathrm{kg}$ of valine, $16-21 \mathrm{mg} / \mathrm{kg}$ of methionine, and $27-36 \mathrm{mg} / \mathrm{kg}$ of threonine. These values are considerably less than the recommended daily allowances $(5,8,14)$ of $70-119 \mathrm{mg} / \mathrm{kg}$ of isoleucine, 64 $105 \mathrm{mg} / \mathrm{kg}$ of valine, $29-45 \mathrm{mg} / \mathrm{kg}$ of methionine, and $45-116$ $\mathrm{mg} / \mathrm{kg}$ of threonine. It appears that the values obtained more closely represent the minimal requirements for the infants studied.

The two infants in this study at 7 months of age experienced satisfactory increments in growth while receiving much lower protein intakes. In the absence of supplemental alanine similar rates of growth in weight were obtained with protein intakes of 0.6 and $0.8 \mathrm{~g} / \mathrm{kg} /$ day. Nitrogen balances were always positive at these levels and while relatively low they were certainly comparable to the $47 \mathrm{mg} / \mathrm{kg}$ recommended for 6 months $(8)$. These might be considered to represent the minimal requirements for protein of these infants. It is possible that these infants studied had lower requirements for essential amino acids than normal infants, as Ruch and Kerr (26) have reported decreased requirements for phenylalanine and leucine, respectively, in infants with phenylketonuria and maple syrup urine disease. However, one would expect decreased catabolism in these conditions in which the metabolic block is so close to the amino acid itself, whereas in disorders of propionate metabolism the site of the defect is very far along the metabolic pathway and there is no evidence for feedback inhibition of earlier steps by the accumulated intermediates. These investigators reasoned appropriately that obligatory catabolism does not stop even at very low levels of protein intake. They defined requirements for phenylalanine and leucine in the infants studied as the amounts tolerated without raising plasma levels above the moderate range. However, their estimates for normal infants were obtained from observations of formula feeding and factorial analysis $(2,7)$ which have led to figures of $1.4 \mathrm{~g} / 100 \mathrm{kcal}$ intake from 4-12 months, along with data on the amino acid composition of human milk, rather than of the proteins ingested by the infants studied, in the generation of this value. Their estimates that $100 \mathrm{kcal} / \mathrm{kg}$ is required at this age would also be generous for the very hypotonic infants we studied. All patients with propionic acidemia and methylmalonic acidemia are very hypotonic in infancy. It may very well be that this hypotonia and diminished muscular activity reduce their requirements for both energy and protein. Kerr et al. (15) have also reported decreased protein catabolism at reduced levels of intake in malnourished infants. Our infants were on adequate caloric intakes and had no evidence of malnutrition. The recommended requirements for protein and nitrogen in infants $0-6$ months old based on studies of normal growth are $2.4-1.4 \mathrm{~g} / \mathrm{kg} / \mathrm{day}$ of protein, $(0.38-0.22 \mathrm{~g} \mathrm{~N} / \mathrm{kg})$ with recommended nitrogen retentions of $180-47 \mathrm{mg} / \mathrm{kg} /$ day $(7,9)$, and in infants 6 months to $3 \mathrm{yr}$ based on factorial analysis the recommendations are for $1.25-0.86 \mathrm{~g} / \mathrm{kg} /$ day of protein $(0.22-0.13 \mathrm{~g} \mathrm{~N} / \mathrm{kg} /$ day) with nitrogen retentions of $91-70 \mathrm{mg} / \mathrm{kg} /$ day (6). These values assume an intake of protein of high biologic value, but with considerable additional nitrogen from other sources in ad libitum diets, and, as such, do not represent minimum requirements for protein.

Acknowledgments. We are pleased to acknowledge the expert technical assistance of Ms. Jan Holm in the analysis of organic acids and Mr. Stanko Kulovich in the analysis of amino acids.

\section{REFERENCES}

1. Ben-Galim E, Hruska K, Bier DM, Matthews DE, Haymond MW 1980 Branched-chain amino acid nitrogen transfer to alanine in vivo in dogs. Direct isotopic determination with $\left({ }^{15} \mathrm{~N}\right)$ leucine. J Clin Invest 66:1295

2. Chan H, Waterlow JC 1966 The protein requirement of infants at the age of about one year. Br J Nutr 20:775

3. Childs B, Nyhan WL 1964 Further observations of a patient with hyperglycinemia. Pediatrics 33:403

4. DeRosa G, Swick RW 1975 Metabolic implications of the distribution of the alanine aminotransferase isoenzymes. J Biol Chem 250:7961

5. FAO/WHO (Food and Agriculture Organization/World Health Organization), 1973. Energy and protein requirements. Report of a joint FAO/WHO ad hoc expert committee. WHO Tech. Rept. Ser. No. S22, FAO Nutrition Meetings Rept. Ser. S2, WHO, Geneva, pp 40-73

6. Felig P 1973 Progress in endocrinology and metabolism, the glucose-alanine cycle. Metabolism 22:179

7. Fomon SJ 1966 Comparative study of adequacy of protein from human milk and cow's milk in promoting $\mathrm{N}$ retention by normal full-term infants. Pediatrics 26:51

8. Fomon SJ, Filer LJ 1967 Amino acid requirements for normal growth. In: Nyhan WL (ed) Amino Acid Metabolism and Genetic Variation. McGrawHill Book Co, New York, pp. 391-401

9. Fomon SJ, May CO 1958 Metabolic studies of normal full-term infants fed pasteurized human milk. Pediatrics 22:101

10. Fomon SJ, Owen GM, Thomas LN 1964 Methionine, valine and isoleucine requirements during infancy. Am J Dis Child 108:487

11. Fomon SJ, Thomas LN, Filer LJ, Anderson TA, Bergman KE 1973 Requirements for protein and essential amino acids in early infancy. Acta Pediatr Scand 62:33

12. Gaull GE 1978 Protein nutrition in the pre-term infant. Acta Pediatr Belg 31:3

13. Goldberg AL, Chang TW 1978 Regulation and significance of amino acid metabolism in skeletal muscle. Fed Proc 37:2301

14. Holt LE, Snyderman SE 1967 The amino acid requirements of children. In: Nyhan WL (ed) Amino Acid Metabolism and Genetic Variation. McGrawHill Book Co., New York, pp 381-390

15. Kerr DS, Stevens MCG, Robinson HM 1978 Fasting metabolism in infants: I. Effect of severe undernutrition on energy and protein utilization. Metabolism $27: 411$

16. Kindt E, Halvorsen S 1980 The need of essential amino acids in children: an evaluation based on the intake of phenylalanine, tyrosine, leucine, isoleucine, and valine in children with phenylketonuria, tyrosine amino transferase defect, and maple syrup urine disease. Am J Clin Nutr 33:279

17. Lozy M, Hegsted DM 1975 Calculation of the amino acid requirements of children at different ages by the factorial method. Am $J$ Clin Nutr 28:1052

18. Manchester KL 1965 Oxidation of amino acids by isolated cat diaphram and the influence of insulin. Acta Biochem Biophys 100:295

19. Miller LL 1962 The role of the liver and the nonhepatic tissues in the regulation of free amino acid levels in the blood. In: Holden JT (ed) Amino Acid Pools, Proceedings of a Symposium on Amino Acids City of Hope Medical Center, Duarte, CA 1961. Elsevier Publishing Co, Amsterdam, pp 708-721

20. Ney D, Bay C, Schneider JA, Kelts D, Nyhan WL 1983 Dietary management of oculocutaneous tyrosinemia in an eleven-year-old. Am J Dis Child $137: 995$

21. Nyhan WL, Bay C, Kelts D 1981 Information on nitrogen metabolism to be learned from inborn errors of metabolism. In: Waterlow JC, Stephen JML (eds) Nitrcgen Metabolism in Man. Applied Science Publishers, Inc, Englewood, NJ pp 77-86 
22. Nyhan WL, Fawcett N, Ando T, Rennert OM, Julius RL 1973 Response to dietary therapy in $B_{12}$ unresponsive methylmalonic acidemia. Pediatrics 51:539

23. Picou D, Phillips M 1972 Urea metabolism in malnourished and recovered children receiving a high or low protein diet. Am J Clin Nutr 25:1261

24. Pozefsky T, Marliss E, Cahill GL 1970 Alanine: key role in gluconeogenesis. Science 167:1003

25. Rose WC, Dekker 1956 Urea as a source of nitrogen for the biosynthesis of amino acids. J Biol Chem 181:107

26. Ruch T, Kerr D 1982 Decreased essential amino acid requirements without catabolism in phenylketonuria and maple syrup urine disease. Am J Clin
Nutr 35:217

27. Satoh T, Narisawa K, Igarashi $Y$, Saitoh T, Hayasaka K, Ichinohazama $Y$, Onodera H, Tada K, Oohara K 1981 Dietary therapy in two patients with vitamin $B_{12}$-unresponsive methylmalonic acidemia. Eur $\mathrm{J}$ Pediatr 135:406

28. Snell K 1980 Muscle alanine synthesis and hepatic gluconeogenesis. Biochem Soc Trans 8:205

29. Snyderman SE 1974 The amino acid requirements of the infant. In: Nyhan WL (ed) Heritable Disorders of Amino Acid Metabolism. John Wiley \& Sons, New York, pp 641-651

30. Snyderman SE, Holt LE, Dancis J, Roitman E, Boyer A, Balis ME 1962

"Unessential" nitrogen: a limiting factor for human growth. J Nutr 78:59

\title{
The Metabolic and Endocrine Milieu of the Human Fetus and Mother at 18-21 Weeks of Gestation. I. Plasma Amino Acid Concentrations
}

\author{
G. SOLTESZ,' D. HARRIS, I. Z. MACKENZIE, AND A. AYNSLEY-GREEN ${ }^{2}$ \\ University Department of Paediatrics, and Nuffield Department of Obstetrics and Gynaecology. John Radcliffe \\ Hospital, Oxford, England
}

\begin{abstract}
Plasma levels of 17 amino acids were measured in $\mathbf{1 0}$ conscious mothers and their minimally stressed fetuses (mean body weight $302 \mathrm{~g}$ ) at 18-21 wk gestation. Simultaneous blood samples were taken from the maternal antecubital vein, and from the fetal umbilical vein and artery by fetoscopy prior to termination of pregnancy. The mean concentrations of all amino acids were significantly higher in the fetal $(2.26 \mathrm{mmol} /$ liter $)$ than in the maternal $(0.96 \mathrm{mmol} / \mathrm{liter})$ circulation, the total molar concentration of amino acids was 2.4 times greater in fetal than in maternal plasma. There was a significant positive relationship between maternal and fetal levels for most amino acids; the mean umbilical concentration difference was significantly positive for glycine, alanine, isoleucine, leucine, phenylalanine, and histidine. (Pediatr Res 19: 91-93, 1985)
\end{abstract}

Abbreviations

AA, amino acids

VA, venous-arterial

UA, umbilical artery

UV, umbilical vein

MV, maternal antecubital vein

The growing human fetus requires a continuous delivery of substrates and fuels, including $\mathrm{AA}$, for the synthesis of new

Received September 7, 1983; accepted August 1, 1984

Requests for reprints should be addressed to Dr. G. Soltesz, Department of Paediatrics, University Medical School, Pecs, Hungary.

${ }^{1}$ Recipient of a Smith and Nephew Fellowship and Visiting Fellow of Green College, Oxford.

2 James Spence Professor of Child Health, University of Newn ule unon Tyne, England. tissue. It has been shown that in most mammals, including man, the umbilical circulation is the only important route by which the fetal body acquires substrates from the maternal environment (2).

Although the umbilical uptake of substrates by the fetus can be measured by the application of the Fick principle (in which umbilical blood flow and venous arterial concentration differences are determined simultaneously), to date, however, accurate measurement of the fetal uptake of the individual AA has been made in only one species, the fetal lamb, and then only late in gestation $(8,9)$.

No human data are available on uptake of AA and information on the circulating concentrations of AA during early gestation is scarce $(3,10,12)$. Moreover, the usefulness of the available data is limited because of the circumstances of blood collection. Thus, earlier studies were performed on fetuses at hysterotomy after placental separation and under maternal anaesthesia $(3,12)$, while only one fetal vessel was sampled in a more recent study in which blood samples were obtained by fetoscopy $(10)$.

In order to overcome these difficulties we have taken advantage of the opportunity to collect simultaneous maternal and fetal artery and vein blood samples during fetoscopy without significant uterine or fetal manipulation. Herein we report results of measurement of plasma AA concentrations. Circulating concentrations of other metabolites, metabolic fuels, and hormones have also been measured and will be reported separately (1).

\section{PATIENTS AND METHODS}

Ten mothers at 18-21 wk gestation (mean $19 \mathrm{wk}$ ) were subjected to fetoscopy and fetal blood sampling immediately before termination of pregnancy for social reasons, within the terms of the 1967 Abortion Act; abortion was induced with intraamniotic instillation of prostaglandin immediately following the fetoscopic procedures. The study was approved by the hospital ethics committee and informed consent was obtained from the mothers. 